\title{
Coastal Erosion Assessment of the Nile Delta Coast using Remote Sensing, GIS, and Modified Coastal Vulnerability Index
}

\author{
Emad F. Abdelaty
}

\begin{abstract}
The coastal zones are very much dynamic and are changing very fast, so it is completely important to study them in a temporal domain, for which remote sensing and GIS are the best tools. The coastal zone along the Governorates of Kafr El Sheikh, Dakahlia, and Damietta in north Egypt are reported to be facing serious environmental challenges. This study evaluates the coastline erosion and accretion and coastal vulnerability index (CVI) along these three Governorates, with a total length of $153 \mathrm{Km}$ over the past 34 years are analyzed using satellite images of TM 1984, ETM+ 2001, and ASTER 2018. The results showed that the study area was exposed to remarkable and non-expected changes over the study periods. Erosion and accretion were found variable over time and place, ranging from 0.14 ha/year in Dakahlia governorate during 1984-2001 to $66.12 \mathrm{ha} /$ year in Kafr El Sheikh Governorate during 2001-2018 for erosion, and from 3.15 ha/year in Dakahlia Governorate at 2001-2018 to 42.45 ha/year in Kafr El Sheikh Governorate at 19842001 for accretion. Total land loss due to erosion as high as about 2034.68 ha of shoreline, and land gain as high as about $\mathbf{1 4 5 9 . 7 1}$ ha of coastline was estimated in the study area with a net of lost lands of about 574.97 ha. In general, Kafr El Sheikh Governorate was more affected by erosion. According to Modified CVI, about $9.66 \%, 11.03 \%$, $33.10 \%$, and $46.21 \%$ of the length of the coastline is classified as very high, high, moderate, and low vulnerability, respectively.
\end{abstract}

Key words: Coastal Erosion, Coastal Accretion, CVI, Satellite Images, Northern Coast, Egypt.

\section{INTRODUCTION}

The earth is a water planet with a total coastline of about 1,634,701 km (Burke et al., 2014). The coastline is the meeting place of land and water, so it is one of the most vital features on the Earth's surface (Winarso and Budhiman, 2001). The coastlines have an abundance of natural resources and urban, for this about one-third of the humans are living close to it (Shetty et al., 2015).

In latest years, the coastal zone has been exposed to pressure and process of changes (Rahisha et al., 2016), and coastal erosion and accretion have long been important processes occurring in many coastal places around the world (Chowdhury and Tripathi, 2013). So, shoreline mapping and monitoring is a very important tool for sustainable coastal development (Hashmi and Ahmad, 2018). Coastal erosion is always accompanied by the shoreward recession of the shoreline and the loss of land area (Saravanan et al., 2014) therefore it has many bad effects on the coastal environment, causing suffering local economies (Bio et al., 2015).

Jones and Boer, (2003) define vulnerability as potential damage caused by a natural hazard. It has often been a quantitative number, which is essential for vulnerability assessment which helps in disaster prevention, management, and mitigation (Romieu et al., 2010). The researchers used several methods for the assessment of coastal vulnerability such as geographic information systems (GIS), remote sensing (RS), dynamic model assessment tools, indicator tools for vulnerability evaluation, and vulnerability indices (Chaib et al., 2020).

The Egyptian Northern coastline extends along the Mediterranean Sea, about $1000 \mathrm{~km}$ (Abdelaty, 2015), and the Nile delta is a dominant feature on it with its economic activities such as agriculture and industry (Eldeberky, 2011). Like other delta's worldwide, the Nile Delta has been experiencing significant shoreline erosion due to natural and human factors (Dewidar and Frihy, 2007), resulting in many serious socioeconomic impacts. Therefore, studying and analyzing this problem can not only mitigate these negative impacts of coastal erosion but also leads to the development of capabilities to deal with future changes.

Using satellite images is an effective means to dynamically monitor coastline change (Abu Zed et al., 2018) and this occurs through integration between remote sensing data and GIS, which is very helpful for measuring and monitoring coastal erosion and accretion, especially in determining the coastline using multitemporal images and overlay temporal maps to measure coastline change detection over time (Rahisha et al., 2016; Chowdhury and Tripathi, 2013). Thus, many researchers have used RS and GIS to study coastal erosion and accretion at a global scale; For example, Saravanan et al., (2014) used RS and GIS for the management of coastal erosion in Southeast of India,
DOI: 10.21608 /asejaiqjsae.2021.188083

${ }^{1}$ Department of Natural Resources \& Agricultural Engineering

Faculty of Agriculture, Damanhour University, Al Abadia Campus,

Damanhour, P.O. Box 22516, Egypt.

Phone: +2 01225023534, Fax: +2 0453282303,

E-mail address: emad.fawzy@agr.dmu.edu.eg

Received July 06, 2021, Accepted, August 08, 2021. 
(Sener et al., 2010; Karsli et al., 2011) used it for shoreline change detection in Turkey. Wang et al., (2013) detected the coastline change in the Pearl River Estuary of China from 1986 to 2011 using six remote sensing images.

Also, for the local scale, numerous studies were carried out to evaluate the coastline change using RS and GIS; for instance, (Frihy et al., 1994; White and El Asmar, 1999) used many satellite images such as MSS, $\mathrm{TM}$, and ETM+ for the determination of coastal erosion. El Fishawi, (1989) found that about $14.7 \mathrm{~km}^{2}$ from Rosetta Promontory was lost from 1909 to 1988, and Blodget et al., (1991) used MSS images to investigate the change detection in the same area between 1972 and 1987. The three TM satellite data were used to measure the changes in the Nile Delta coastline from 1984 to 1991 (White and El Asmar, 1999). The results of Elsayed and Mahmoud, (2007) showed that Rosetta Promontory lost $113.8 \mathrm{~m}$ annually between 1984 and 1991.

Thus, the aim and the novel work of the present study is to integrate RS and GIS (Digital Shoreline Analysis System (DSAS) as an available extension that works within ArcGIS software) to the assessment of Coastal Vulnerability Index (CVI). Additionally, estimate and mapping coastal erosion and accretion and its rates along the coastline of Kafr El Sheikh, Dakahlia, and Damietta Governorates between 1984 and 2018 using remote sensing and GIS as tools to demarcate the eroding zones along the coastline that can be used efficiently by decision-makers to devise an effective coastal zone management plan in the study area.

\section{STUDY AREA}

In this present study, the coastline of the study area is situated between the Rosetta River Nile branch in the west (249952.76 E and $3484780.86 \mathrm{~N}$ ) and Dumyat River Nile branch in the east (390247.88 E 3488689.21 $\mathrm{N})$ and with a total coastline length of about $153 \mathrm{~km}$ which protect the Nile delta from flooding.

This zone presents a major part of the Nile delta coast of Egypt and forms one of the main socioeconomic areas of Egypt with more population inhabiting the coastal areas, as well as incorporating many industries, mining sites, and other developmental projects.

The study area includes the coastline of three Egyptian Governorates that extend from west to east as follows; Kafr El Sheikh coastline, which presents about $96 \mathrm{~km}$, Dakahlia coastline which extends about $26 \mathrm{~km}$, and Damietta coastline which presents about $31 \mathrm{~km}$ (Figure 1).

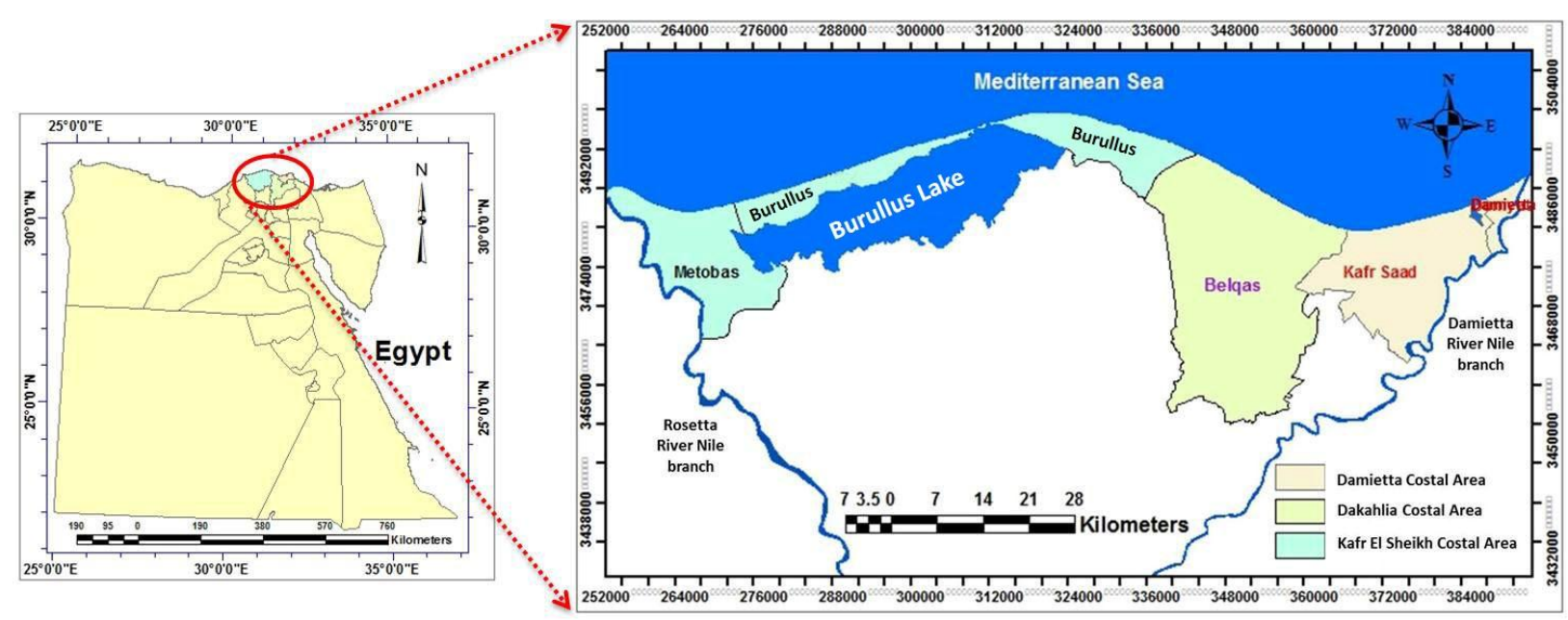

Fig. 1. Study area map 


\section{MATERIAL AND METHODS}

The current study was divided into five interrelated phases as shown in Figure (2) as a research methodology flowchart. That methodology including:

Data Sources: The LandSat archive data for different years (TM 1984, ETM+ 2001) and ASTER data (2018) were downloaded from the website (EarthExplorer, 2015) and used for this study region with Universal Transverse of Mercator (UTM), zone $36 \mathrm{~N}$. Two Landsat 5 (TM) images, two Landsat 7 (ETM+) images, and four ASTER images were used to extract and digitize vector shoreline data. The following Table (1) shows the characteristics of those images.

Coastline digitizing: The coastline feature was drawn using screen digitizing in Arc-GIS 10.2 environment (ArcMap 10.2, 2008).

Coastline change detection: The Digital Shoreline Analysis System (DSAS) is a free and available extension that works within ArcGIS software (ArcMap $10.2,2008$ ). DSAS is used to calculate the rate of coastline change using digitized shoreline for the years 1984, 2001, and 2018 in the vector format.

Software: Environment for Visualizing Images (ENVI $4.7,2009$ ) was used for satellite images processing and thresholding of the land-sea boundary for extraction of shorelines. Therefor (ArcMap 10.2, 2008) was used for digitization of topographic maps and generalization of extracting shorelines.

Coastal Vulnerability Index (CVI): Physical vulnerability index (PVI) parameters (Coastal slope, Geomorphology, Elevation, Shoreline change, Sea level change, Significant wave height, and Tidal range) and Social vulnerability index (SVI) parameters (Population, Land use/land cover, Road network, and Tourist areas) are used to calculate the Coastal Vulnerability Index (CVI) (Murali et al., 2013).

The six most important variables based on the coastal conditions of the study area were selected to calculate the modified Coastal Vulnerability Index (CVI): a: shoreline change rate $(\mathrm{m} / \mathrm{y})$, b: Land use/Land cover, c: coastal geomorphology, d: regional elevation (m), e: coastal slope (degree), and f: road network (distance from the shoreline). The CVI was calculated as the square root of the results of the ranked variables divided by the total number of variables (Ahammed et al., 2016) as shown in the following equation. Risk ratings for selected parameters have been assigned in Table (2) according to Murali et al., 2013.

$$
C V I=\sqrt{ }(a * b * c * d * e * f) / n
$$

Table1. Satellite images and their sensor specification used in the study

\begin{tabular}{|c|c|c|c|}
\hline \multirow{2}{*}{ Specification } & \multicolumn{3}{|c|}{ Satellite } \\
\hline & Landsat 5 & Landsat 7 & ASTER \\
\hline Sensor & $\begin{array}{l}\text { Thematic Mapper } \\
\text { (TM) }\end{array}$ & $\begin{array}{l}\text { Enhanced Thematic } \\
\text { Mapper Plus (ETM+) }\end{array}$ & $\begin{array}{l}\text { Advanced Space-borne } \\
\text { Thermal Emission and } \\
\text { Reflection Radiometer }\end{array}$ \\
\hline Spectral Resolution (bands) & 7 & 8 & 14 \\
\hline Spatial Resolution (m) & $\begin{array}{l}\text { bands } 1 \text { to } 5 \text { and } 7 \\
(30 \mathrm{~m})-\text { band } 6 \\
(120 \mathrm{~m})\end{array}$ & $\begin{array}{l}\text { bands } 1 \text { to } 5 \text { and } 7(30 \mathrm{~m}) \\
\text { - band } 6(60 \mathrm{~m})-\text { band } 8 \\
(15 \mathrm{~m})\end{array}$ & $\begin{array}{c}\text { bands } 1 \text { to } 3(15 \mathrm{~m})-\text { bands } \\
4 \text { to } 9(30 \mathrm{~m})-\text { bands } 10 \text { to } \\
14(90 \mathrm{~m})\end{array}$ \\
\hline Radiometric Resolution (bit) & 8 bit & 8 bit & $\begin{array}{c}\text { bands } 1 \text { to } 9 \text { (8 bit) - bands } \\
10 \text { to } 14(12 \text { bit })\end{array}$ \\
\hline Temporal Resolution (days) & & 16 days & \\
\hline Acquired Date & 1984 & 2001 & 2018 \\
\hline Coordinate System/Datum & & UTM/WGS 84 & \\
\hline Zone & & 36 & \\
\hline Source & & (EarthExplorer, 2015) & \\
\hline
\end{tabular}




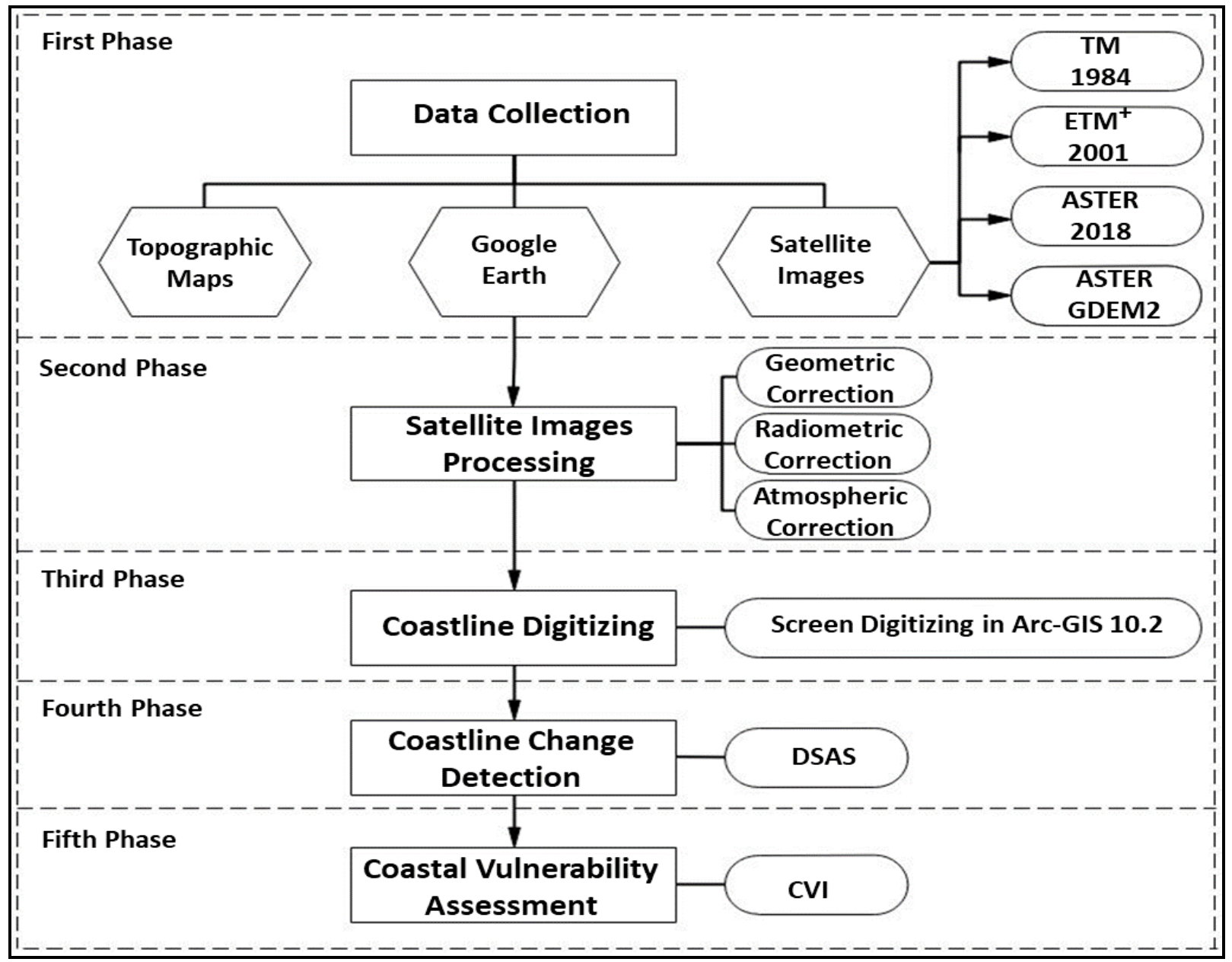

Fig. 2. Research methodology flowchart

Table 2. Risk rating assigned for different parameters (Murali et al., 2013)

\begin{tabular}{|c|c|c|c|c|}
\hline \multirow{2}{*}{ Variable } & \multicolumn{4}{|c|}{ Risk Rating } \\
\hline & Low (1) & Moderate (2) & High (3) & Very high (4) \\
\hline $\begin{array}{c}\text { a- Shoreline } \\
\text { change rate }(\mathrm{m} / \mathrm{y})\end{array}$ & $\begin{array}{l}>10 \text { (high } \\
\text { accretion) }\end{array}$ & 0-10 (accretion) & $\begin{array}{c}\geq-10 \text { and }<0 \\
(\text { erosion })\end{array}$ & $\begin{array}{c}<-10 \text { (severe } \\
\text { erosion) }\end{array}$ \\
\hline $\begin{array}{l}\text { b- Land use/Land } \\
\text { cover }\end{array}$ & $\begin{array}{l}\text { Wetlands, Salt } \\
\text { marshes, } \\
\text { Open lands, River } \\
\text { and Inlets mouths } \\
\text { (low capital) }\end{array}$ & $\begin{array}{c}\text { Mangroves, Dune } \\
\text { vegetations, } \\
\text { Vegetations } \\
\text { (moderate capital) }\end{array}$ & $\begin{array}{l}\text { Scattered villages, } \\
\text { Agricultural lands, } \\
\text { Saltpans (high } \\
\text { capital) }\end{array}$ & $\begin{array}{l}\text { Hotels, Jetties, } \\
\text { Fisheries (very } \\
\text { high capital) }\end{array}$ \\
\hline c- Geomorphology & Rocky coast & $\begin{array}{c}\text { Embayed/indented } \\
\text { coast }\end{array}$ & $\begin{array}{l}\text { Dunes/estuaries } \\
\text { and lagoons }\end{array}$ & $\begin{array}{c}\text { Mudflats, } \\
\text { mangroves, } \\
\text { beaches, barrier- } \\
\text { spits }\end{array}$ \\
\hline d- Elevation (m) & $>6$ & $>3$ and $<6$ & $>0$ and $<3$ & $<0$ \\
\hline $\begin{array}{l}\text { e- Coastal slope } \\
\text { (Degree) }\end{array}$ & $0-10$ & $11-20$ & $21-45$ & $>45$ \\
\hline $\begin{array}{r}\text { f- Road network } \\
\text { (distance from) }\end{array}$ & $2 \mathrm{~km}$ buffer & $1 \mathrm{~km}$ buffer & $500 \mathrm{~m}$ buffer & $250 \mathrm{~m}$ buffer \\
\hline
\end{tabular}


An overall Coastal Vulnerability Index (CVI) is further computed of each $1 \mathrm{~km}$ segment (total of 145 segments) of the shoreline, and it was mapped within the littoral zone extending $1 \mathrm{~km}$ landward from the shoreline. The calculate of CVI involves data obtained from various sources, as in Table (3).

Table 3. Parameters used in this study and its data sources

\begin{tabular}{ll}
\hline \multicolumn{1}{c}{ Variables } & \multicolumn{1}{c}{ Sources } \\
\hline a- Shoreline & Landsat TM, Landsat ETM ${ }^{+}$, \\
change rate (m/y) & ASTER (EarthExplorer, 2015) \\
b- Land use/Land & Topographic maps, ASTER, \\
cover & Google Earth \\
c-Geomorphology & Geological maps, ASTER, \\
& Google Earth \\
d- Elevation (m) & ASTER GDEM 2 \\
e- Coastal slope & Extracted from the digital \\
(Degree) & elevation model \\
f- Road network & Topographic maps, ASTER, \\
(distance from) & Google Earth \\
\hline
\end{tabular}

\section{RESULTS AND DISCUSSION}

\section{Shoreline change and coastal erosion hazard}

The coastal zones are a source of economy, used as tourists attraction, while erosion is a great threat to the economy and human life. So, a remote sensing-based vulnerability assessment approach of erosion is crucial to generate detailed vulnerability information to support coastal development strategies. To estimate the rate of change of coastline on the study area, 1984 to 2018 coastline are investigated. The coastline of three Governorates (Kafr El Sheikh, Dakahlia, and Damietta) has been delineated during different periods using Satellite data of 1984, 2001, and 2018.

The extents of the shoreline accreting or eroding for the periods 1984- 2001 and 2001-2018 are shown in Table (4) of the entire length of $153 \mathrm{~km}$. The extreme erosion is specifically observed at Kafr El Sheikh governorate coastline in the period from 2001 to 2018 as shown in Table (4) and Figure (3).

Table 4. The coastal erosion and accretion made in the Governorates of the study area

\begin{tabular}{llcccccc}
\hline & \multirow{2}{*}{$\begin{array}{c}\text { Area } \\
\text { and }\end{array}$} & \multicolumn{6}{c}{ Governorate } \\
\cline { 3 - 8 } Process & \multicolumn{2}{c}{ Kafr El Sheikh } & \multicolumn{2}{c}{ Dakahlia } & \multicolumn{2}{c}{ Damietta } \\
\cline { 3 - 8 } & \multicolumn{1}{c}{ Annual Rate } & $\mathbf{1 9 8 4}$ & $\mathbf{2 0 0 1}$ & $\mathbf{1 9 8 4}$ & $\mathbf{2 0 0 1}$ & $\mathbf{1 9 8 4}$ & $\mathbf{2 0 0 1}$ \\
& & $\mathbf{2 0 0 1}$ & $\mathbf{2 0 1 8}$ & $\mathbf{2 0 0 1}$ & $\mathbf{2 0 1 8}$ & $\mathbf{2 0 0 1}$ & $\mathbf{2 0 1 8}$ \\
\hline \multirow{2}{*}{ Erosion } & Area (ha) & 622.67 & 1124.07 & 2.30 & 99.34 & 84.07 & 102.22 \\
& Annual Rate (ha/year) & 36.63 & 66.12 & 0.14 & 5.84 & 4.95 & 6.01 \\
\multirow{2}{*}{ Accretion } & Area (ha) & 721.59 & 125.16 & 224.60 & 53.69 & 210.40 & 124.25 \\
& Annual Rate (ha/year) & 42.45 & 7.36 & 13.21 & 3.15 & 12.38 & 7.30 \\
\hline
\end{tabular}

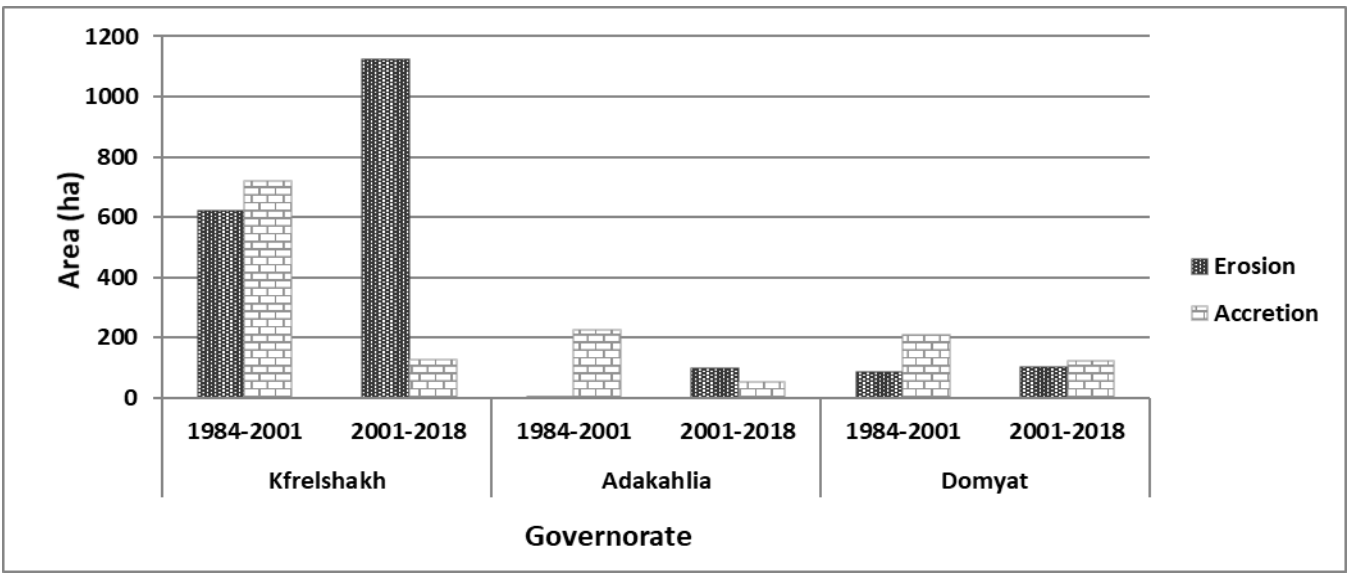

Fig.3. Eroded and accreted areas at different Governorates for different periods 
Table 5. Total area (ha) and annual rate (ha/year) of erosion and accretion

\begin{tabular}{ccccccc}
\hline \multirow{2}{*}{ Period } & \multicolumn{3}{c}{ Erosion } & \multicolumn{3}{c}{ Accretion } \\
\cline { 2 - 5 } & Total Area & Annual Rate & $\%$ & Total Area & Annual Rate & \multirow{2}{*}{$\%$} \\
\cline { 2 - 5 } & (ha) & (ha/Year) & & (ha) & (ha/Year) & \\
\hline $1984-2001$ & 709.05 & 41.71 & & 1156.60 & 68.04 & \\
$2001-2018$ & 1325.63 & 77.97 & 58.23 & 303.11 & 17.83 & 41.77 \\
$1984-2018$ & 2034.68 & 59.84 & & 1459.71 & 42.93 & \\
\hline
\end{tabular}

The total eroded and accreted areas during the whole period (1984 to 2018) were 2034.68 and 1459.71 ha, respectively, and about $58 \%$ of the shoreline is observed to be eroding over 34 years (Table 5). The shoreline changes from 2001 to 2018 show an extreme annual rate of erosion (77.97 ha/year). And from 1984- 2001 annual rate of accretion was $68 \mathrm{ha} /$ year.

Overall, from 1984-2018, the shoreline analysis of this coastline $(153 \mathrm{~km})$, shows that the annual eroding trend was $59.84 \mathrm{ha} /$ year, and the annual rate of accretion was 42.93 ha/year. About 2034.68 ha of land were eroded in the study area and on the other hand, there had been an accretion of about 1459.71 ha.

Table (6) shows that the maximum negative net growth observed in Kfrelshakh Governorate (-899.99 ha) with a rate of -26.47 ha/year, whereas the total erosion rate is more than the total accretion rate. On the other hand, the accretion is more in Dakahlia and Damietta Governorates with a positive net growth of about 176.65 and 148.37 ha, and the coastline is accreting at a rate of 5.19 and $4.36 \mathrm{ha} / \mathrm{year}$, respectively.

In general, total land loss due to erosion is about 2034.68 ha of shoreline, and land gain is about 1459.71 ha of coastline in whole the study area with a net of lost lands of about 574.97 ha.
Assessment and mapping of Kafr El Sheikh Governorate shoreline erosion and accretion

The period from 1984 to 2001

The analysis of the shoreline changes between 1984 and 2001 is shown in Figure (3). About 622.67 ha of land were eroded from the shoreline in the Kafr El Sheikh Governorate. However, there had been an accretion of about 721.59 ha at the same time in the area.

\section{The period from 2001 to 2018}

Figure (3) also shows shoreline remarkable changes between 2001 and 2018. About 1124.07 ha of land were eroded from the shoreline in this part of the study area. Also, it shows an area of gain (accretion), about 125.16 ha.

In a span of 17 years (2001-2018) Kafr El Sheikh Governorate has experienced maximum erosion among all the Governorates of the entire study area, and it faces severe erosion threat especially in its western part (Figure 4). This is maybe because of river mouse as well as human activities. The temporal comparison between various satellite images of Kafr El Sheikh western part displays the significant reclamation of the coastal zone and using this part as fish farms under Egyptian strategy for the development of the north coast.

Table 6. Erosion and accretion during 1984-2018 in the study area

\begin{tabular}{ccccc}
\hline Erosion and accretion & \multicolumn{3}{c}{ Governorate } & \multirow{2}{*}{ Total Area } \\
\cline { 1 - 4 } during 1984-2018 & Kafr El Sheikh & Dakahlia & Damietta & \\
\hline Total Area (ha) & 2593.50 & 379.93 & 520.95 & 3494.38 \\
Total Erosion (ha) & 1746.75 & 101.64 & 186.29 & 2034.68 \\
Total Accretion (ha) & 846.75 & 278.29 & 334.66 & 1459.7 \\
Erosion \% & 67.35 & 26.75 & 35.76 & 129.86 \\
Acceration \% & 32.65 & 73.25 & 64.24 & 170.14 \\
Net Growth (ha) & -899.99 & 176.65 & 148.37 & -574.97 \\
Growth rate (ha/year) & -26.47 & 5.19 & 4.36 & -16.92 \\
\hline
\end{tabular}



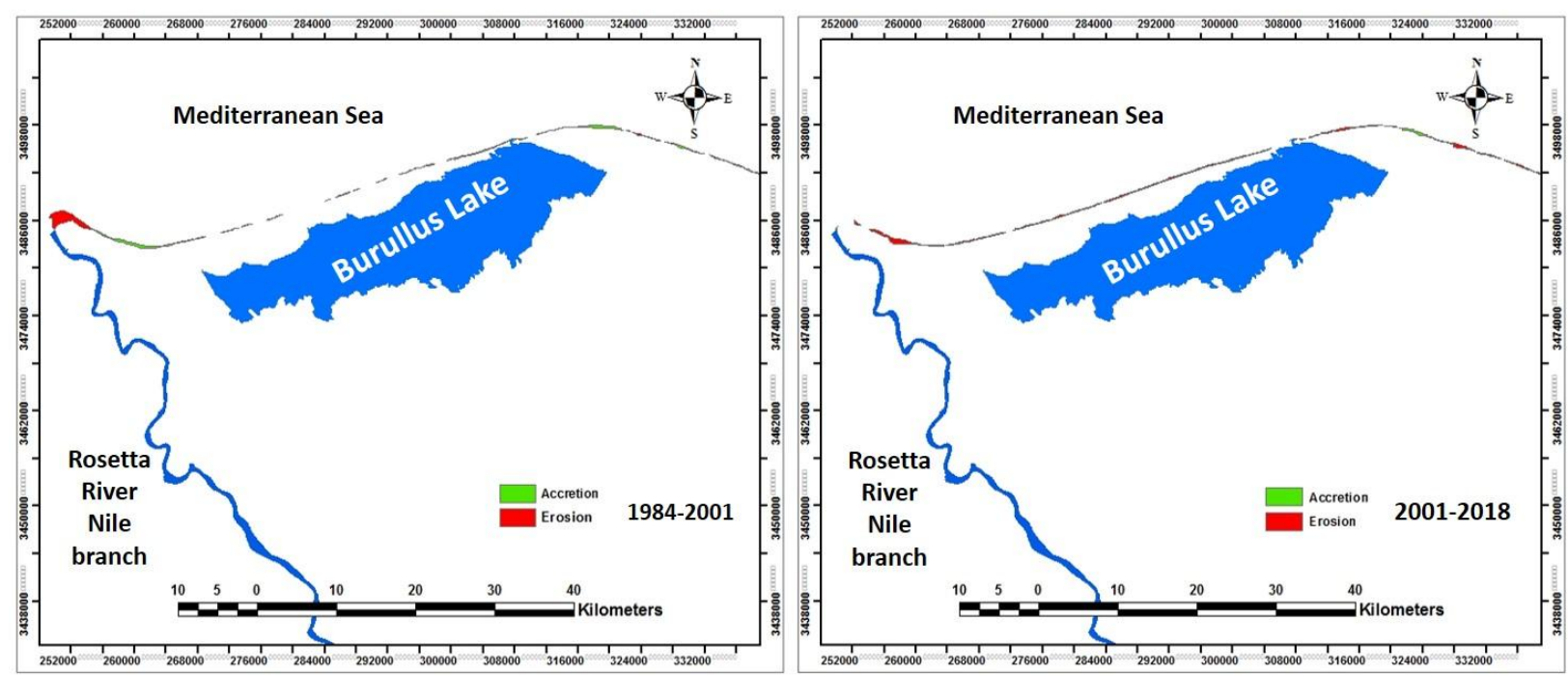

Fig.4. Total area of erosion and accretion in Kafr El Sheikh Governorate

Assessment and mapping of Dakahlia Governorate shoreline erosion and accretion

\section{The period from 1984 to 2001}

There were considerable shoreline changes in this Governorate from 1984 to 2001. There was less shoreline erosion (only 2.30 ha) in the study area. However, there was more accretion during this period, which formed a continuous piece of land with an area of
224.60. In a span of 17 years (1984-2001) this Governorate has shown minimum erosion (Figure 3).

\section{The period from 2001 to 2018}

Between 2001 and 2018 about 99.34 ha of land, were eroded from the shoreline in the Dakahlia Governorate, the green color in the photomap, whereas the red color represents the accreted area which was about 53.69 ha over the same period (Figure 5).
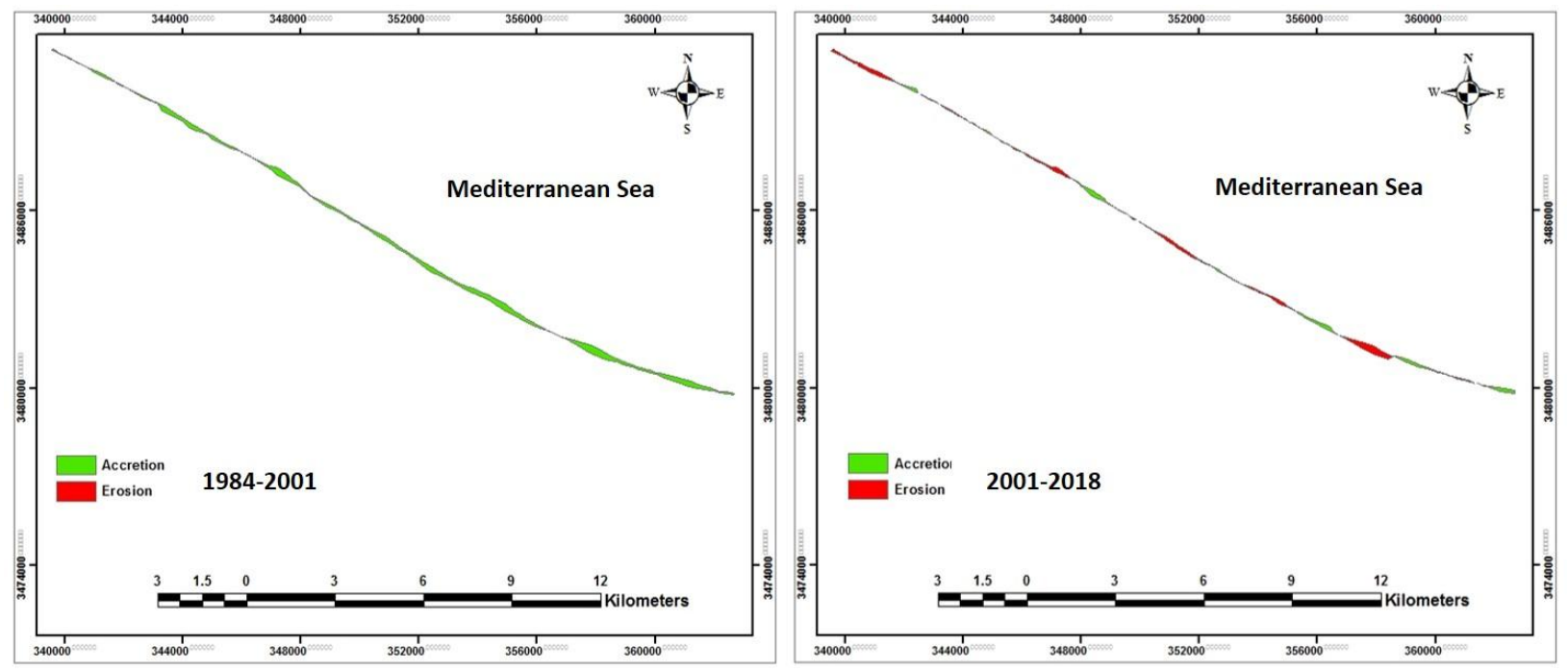

Fig.5. Total area of erosion and accretion in Dakahlia Governorate 
Assessment and mapping of Damietta Governorate shoreline erosion and accretion

\section{The period from 1984 to 2001}

During 1984-2001 about 84.07 ha of land was eroded from the Damietta Governorate, red color in the photomap in Figure (6). There was a more accretion of about 210.40 ha in the area colored with green.

\section{The period from 2001 to 2018}

Figure (6) also shows the shoreline change between 2001 and 2018. About 102.22 ha of land were eroded from the shore in Damietta Governorate. Also, it shows the accretion area, which measures 124.25 ha.

\section{Assessment and mapping of Coastal Vulnerability Index (CVI)}

The main purpose of coastal vulnerability assessments is to be an indicator for scientists, and policymakers to improve their understanding of coastlines changes. This understanding gives better management of the coastline, as management efforts can be oriented for especially vulnerable areas (Hinkel and Klein, 2009). The coastal vulnerability assessment in wide form involves calculating an index to simplify several complex and interacting parameters to a form that is more easily understood (McLaughlin et al., 2010).

The minimum value of the coastal vulnerability index in this study is 1.15 and the maximum value is 11.31. Therefore, the CVI values were separated into 4 class intervals as low, moderate, high, and very high (Table 7).

Figure (7) shows the percentage of CVI and its parameters in the study area. The coastal slope is recorded high vulnerability compared to other parameters, then following by land use/land cover, shoreline change rate, and road network; it means that these parameters are controlling factors for coastal vulnerability.

The very highly Vulnerable Index is recorded in Kafr El Sheikh Governorate, with an 11.31 index value and the lowest vulnerable index was recorded in Damietta Governorate with a 1.15 index value. The results indicate that about $9.66 \%$ are categorized under very high vulnerability and it comes $14.77 \mathrm{~km}$ length of the study area. About $11.03 \%$ of the total coastline is classified as high vulnerability $(16.88 \mathrm{Km})$. Moderate and low vulnerable areas contributing $33.10 \%$ and $46.21 \%$, which cover $50.65 \mathrm{Km}$ and $70.70 \mathrm{Km}$ of the total coastline, respectively (Figure 7).

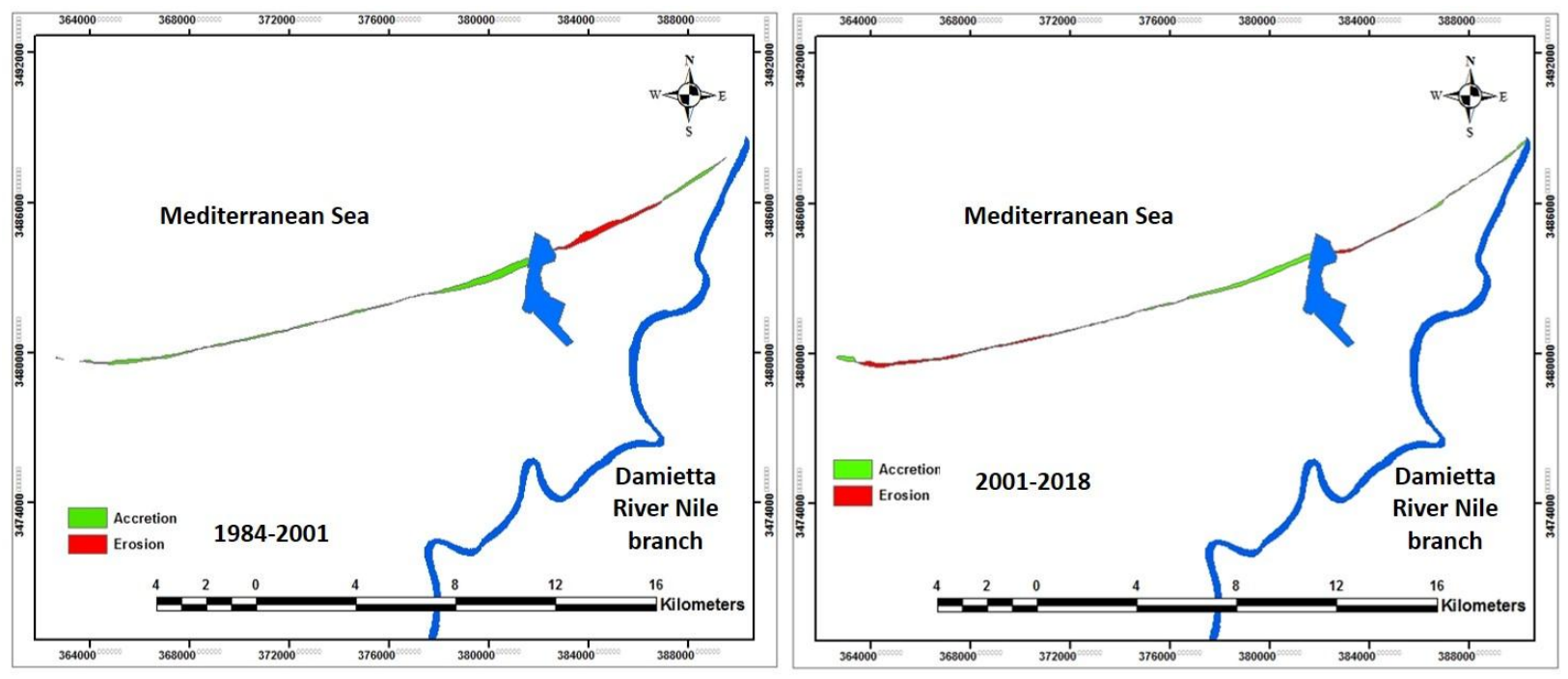

Fig.6. Total area of erosion and accretion in Damietta Governorate

Table 7. Classes of Coastal Vulnerability Index

\begin{tabular}{lllll}
\hline \multicolumn{5}{c}{ CVI } \\
\hline Risk & Low Vulnerable & Moderate Vulnerable & Highly Vulnerable & Very highly Vulnerable \\
Value & $1.15-3.69$ & $>3.69-6.23$ & $>6.23-8.77$ & $>8.77-11.31$ \\
\hline
\end{tabular}




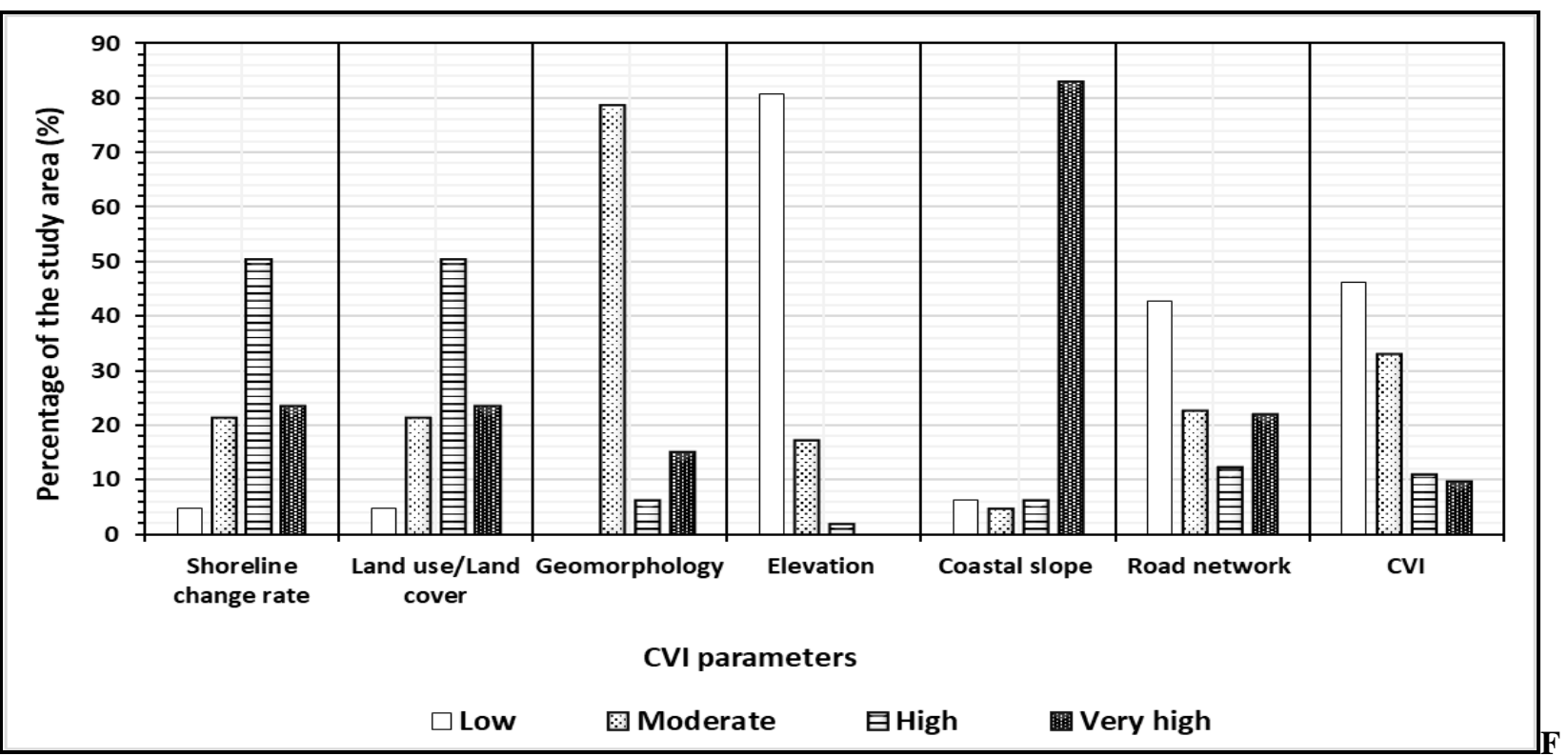

Fig. 7. The percentage of CVI and its parameters in the study area

The very highly vulnerable area was recorded in two places through the coastline; the first one was located at the point of connecting Burullus lake with the Mediterranean Sea, and the second place was sited in the Eastern part of the study area when the Damietta River Nile branch connects with the Mediterranean Sea.
The highly vulnerable area was in three places; the first one was placed in the western part of the study area when the Rosetta River Nile branch connects with the Mediterranean Sea, the second one was placed in the area between Dakahlia Governorate and Damietta Governorate, and the third place was in the front of the new Damietta city. Moderate and Low Vulnerable were spread across the coastline (Figure 8).

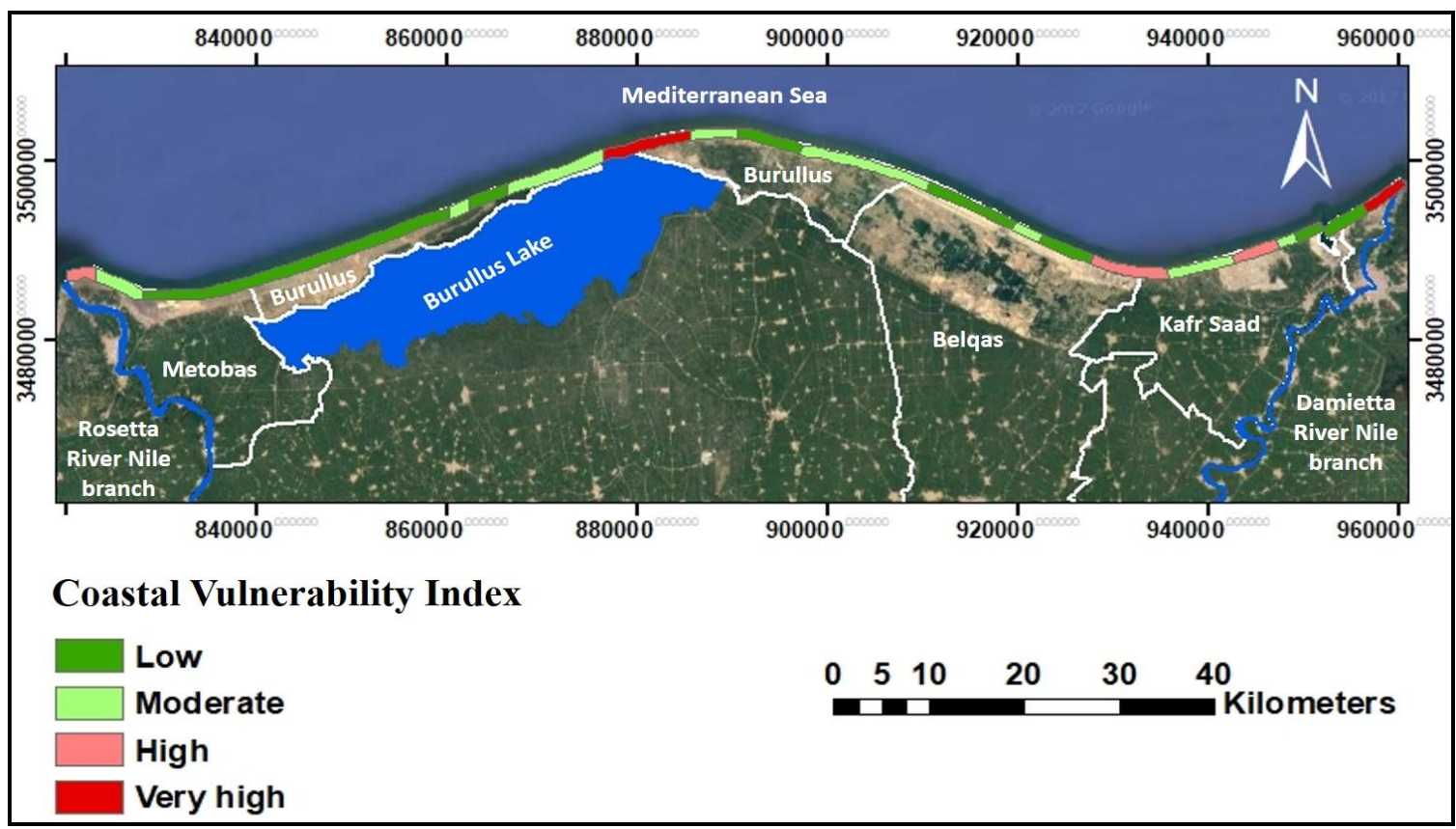

Fig. 8. Coastal Vulnerability Index in the study area 


\section{CONCLUSIONS}

Lack of coastal zone management has caused severe environmental problems such as land subsidence, coastal erosion, the intrusion of saltwater, degradation of agricultural land. This paper analyzed coastline change, erosion-accretion evolution, by using remote sensing data and geographical information system technology. The study has revealed that during the study period of 33 years, coastal erosion is predominant over accretion and major erosion is evidenced in all the study area during 2001-2018.

Erosion is highest on the coast of Kafr El Sheikh governorate $(67.35 \%)$ with a net growth of about (899.99 ha), but accretion is highest in Dakahlia governorate $(73.25 \%)$ with a net growth of about (176.65 ha). The coastal zone along the governorates of Kafr El Sheikh, Dakahlia, and Damietta in North Egypt are reported to be facing serious environmental challenges. The results of this study are very valuable for the decision-makers who are interested in the sustainable development of the Egyptian north coast and protecting the Nile Delta from coastal erosion.

Coastal Vulnerability Index highlights the more challenging parts (high and very highly vulnerable) along the coastline that demand further attention. Accordingly, the preliminary planning can be applied using the results of this study in the conservation of the coastal zone in the Nile delta.

\section{REFERENCES}

Abdelaty, E.F. 2015. GIS-mapping aridity and rainfall water deficit of Egypt. J.Agric.\&Env.Sci.Dam.Univ.,Egypt, Vol.14 (2), 17-40.

Abu Zed, A.A., M.R. Soliman and A.A. Yassin. 2018. Evaluation of using satellite image in detecting long term shoreline change along El-Arish coastal zone, Egypt. Alexandria Eng J 57:2687-2702. https://doi.org/10.1016/j.aej.2017.10.005

Ahammed, B.K.K., R.S. Mahendra and A.C. Pandey. 2016. Coastal Vulnerability Assessment for Eastern Coast of India, Andhra Pradesh by Using Geo-Spatial Technique. Geoinfor Geostat: An Overview 4:3. http://dx.doi.org/10.4172/2327-4581.1000146

ArcMap 10.2. 2008. ESRI, Environmental Systems Research Institute.

Bio, A., L. Bastos, H. Granja, J.L.S. Pinho, J.A. Goncalves, R. Henriques, S. Madeira, A. Magalhaes and D. Rodrigues. 2015. Methods for coastal monitoring and erosion risk assessment: Two Portuguese case studies. J Integr Coast Zo Manag 15:47-63. https://doi.org/10.5894/rgci490.

Blodget, H.W., P.T. Taylor and J.H. Roark. 1991. Shoreline changes along the Rosetta-Nile Promontory: Monitoring with satellite observations. Mar Geol 99:67-77. https://doi.org/10.1016/0025-3227(91)90083-G.
Burke, L., Y. Kura, K. Kassem, C. Revenga, M. Spalding and D. Mcallister. 2014. Coastal ecosystems. World Resources Institute Washington, DC.

Chaib, W., M. Guerfi and Y. Hemdane. 2020. Evaluation of coastal vulnerability and exposure to erosion and submersion risks in Bou Ismail Bay (Algeria) using the coastal risk index (CRI). Arab J Geosci 13:. https://doi.org/10.1007/s12517-020-05407-6.

Chowdhury, S.R. and N.K. Tripathi. 2013. Coastal erosion and accretion in Pak Phanang, Thailand by GIS analysis of maps and satellite imagery. Songklanakarin J Sci Technol 35:739-748.

Dewidar, K. and O. Frihy. 2007. Pre- and post-beach response to engineering hard structures using Landsat time-series at the northwestern part of the Nile delta, Egypt. J Coast Conserv 11:133-142. https://doi.org/10.1007/s11852-0080013-z.

EarthExplorer. 2015. https://earthexplorer.usgs.gov/. Accessed 19 Jan 2021.

El Fishawi, N. 1989. Coastal erosion in relation to sea level changes, subsidence and river discharge, Nile delta coast. Acta Mineral 30:161-170.

Eldeberky, Y. 2011. Coastal adaptation to sea level rise along the Nile delta, Egypt. WIT Trans Ecol Environ 149:41-52. https://doi.org/10.2495/CP110041.

Elsayed, M.A.K. and S.M. Mahmoud. 2007. Groins System for Shoreline Stabilization on the East Side of the Rosetta Promontory, Nile Delta Coast. J Coast Res 232:380-387. https://doi.org/10.2112/04-0319.1.

ENVI 4.7. 2009. Exelis Visual Information Solutions.

Frihy, O.E., S.M. Nasr, M.M. El Hattab and M. El Raey. 1994. Remote sensing of beach erosion along the Rosetta promontary, Northwestern Nile Delta, Egypt. Int J Remote Sens 15:1649-1660. https://doi.org/10.1080/01431169408954197.

Hashmi, D.S.G. and S. Ahmad. 2018. GIS-Based Analysis and Modeling of Coastline Erosion and Accretion along the Coast of Sindh Pakistan. J Coast Zo Manag 21:1-7. https://doi.org/10.4172/2473-3350.1000455.

Hinkel, J. and R.J.T. Klein. 2009. Integrating knowledge to assess coastal vulnerability to sea-level rise: The development of the DIVA tool. Glob Environ Chang 19:384-395. https://doi.org/10.1016/j.gloenvcha.2009.03.002.

Jones, R. and R. Boer. 2003. Assessing current climate risks. In: Adaptation Policy Frameworks for Climate Change: Developing Strategies, Policies and Measures. pp 91-117.

Karsli, F., A. Guneroglu and M. Dihkan. 2011. Spatiotemporal shoreline changes along the southern Black Sea coastal zone. J Appl Remote Sens 5:053545. https://doi.org/10.1117/1.3624520.

McLaughlin, S., J. Andrew and G. Cooper. 2010. A multiscale coastal vulnerability index: A tool for coastal managers? Environ Hazards 9:233-248. https://doi.org/10.3763/ehaz.2010.0052. 
Murali, R.M., M. Ankita, S. Amrita and P. Vethamony. 2013. Coastal vulnerability assessment of Puducherry coast, India, using the analytical hierarchical process. Nat Hazards Earth Syst Sci 13:3291-3311. https://doi.org/10.5194/nhess-13-3291-2013.

Rahisha, T., K.C. Goud and V. Sreedhara. 2016. Change Detection in Mangalore Coastline Using Multi. Int $\mathbf{J}$ Adv Mech Civ Eng 9-14.

Romieu, E., T. Welle, S. Schneiderbauer, M. Pelling and C. Vinchon. 2010. Vulnerability assessment within climate change and natural hazard contexts: Revealing gaps and synergies through coastal applications. Sustain Sci 5:159170. https://doi.org/10.1007/s11625-010-0112-2.

Saravanan, S., N. Chandrasekar, M. Rajamanickam, C. Hentry and V. Joevivek. 2014. Management of Coastal Erosion Using Remote Sensing and GIS Techniques (SE India). Int J Ocean Clim Syst 5:211-221. https://doi.org/10.1260/1759-3131.5.4.211.

Sener, E., A. Davraz and S. Sener. 2010. Investigation of Aksehir and Eber lakes (SW Turkey) coastline change with multitemporal satellite images. Water Resour Manag 24:727-745. https://doi.org/10.1007/s11269-009-9467-5.

Shetty, A., K.S. Jayappa and D. Mitra. 2015. Shoreline Change Analysis of Mangalore Coast and Morphometric Analysis of Netravathi-Gurupur and Mulky-pavanje Spits. Aquat Procedia 4:182-189. https://doi.org/10.1016/j.aqpro.2015.02.025.

Wang, X., H. Zhang, B. Fu and A. Shi. 2013. Analysis on the coastline change and erosion-accretion evolution of the Pearl River Estuary, China, based on remote-sensing images and nautical charts. J Appl Remote Sens 7:073519. https://doi.org/10.1117/1.jrs.7.073519.

White, K. and H.M. El Asmar. 1999. Monitoring changing position of coastlines using Thematic Mapper imagery, an example from the Nile Delta. Geomorphology 29:93-105. https://doi.org/10.1016/S0169-555X(99)00008-2.

Winarso, G. and S. Budhiman. 2001. The application remote sensing data for coastal study. 22nd Asian Conf Remote Sens 1:5-9.

\section{الملخص العربي \\ تقييم التعرية الساحلية لساحل دلتا النيل باستخدام الاستشعار عن بعد ونظم المعلومات الجغرافية ومؤثر الضعف الساحلي المعدل$$
\text { عماد فوزي عبد العاطي }
$$

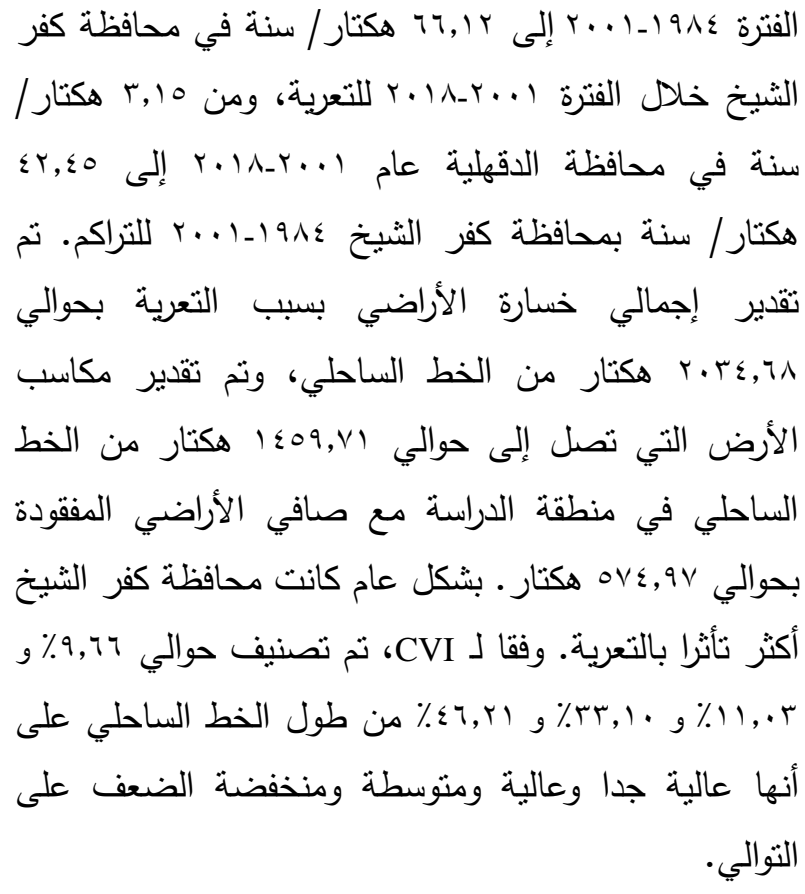$$
\text { التوالي. }
$$

حيث أن المناطق الساحلية تعتبر ديناميكية للغاية وتتغير بسرعة كبيرة، لللك من المهم تماما دراستها في نطاق زمني محدد، ويعتبر الاستشعار عن بعد ونظم المعلومات الجغرافية أفضل الأدوات لذلك. تشير التقارير إلى أن المنطقة الساحلية على طول محافظات كفر الثيخ والدقهلية ودمياط في شمال مصر تواجه تحديات بيئية خطيرة. تقوم هذه الدراسة بتقييم تآكل وتراكم الساحل ومؤشر الضعف الساحلي (CVI) على طول هذه المحافظات الثلاث، بطول إجمالي يبلغ سم 10 كم على مدى السنوات الـ ؟r الماضية، ويتم تحليلها باستخدام

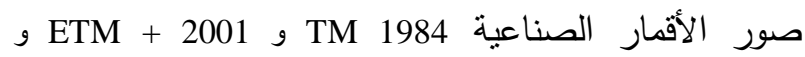
ASTER 2018 وأظهرت النتائج أن منطقة الدراسة تعرضت ورته لتغيرات ملحوظة وغير متوقعة خلال فترات الدراسة. تم العثور على تآكل وتراكم متغير بمرور الوقت والمكان، حيث تراوحت بين ؟ ا, . هكتار/ سنة في محافظة الدقهلية خلال 